\title{
Frequency of MRSA Isolates in Mobile Phones, Ears and Hands of Healthcare Workers
}

\section{Mawada Bakri Osman, Safia Mohammed Omer, Babiker Saad Almugadam and Hana Mohammed Ahmed*}

Department of Microbiology, Faculty of Medical Laboratory Sciences, University of Elimam Elmahdi, Kosti City, Sudan

*Corresponding author: Hana Mohammed Ahmed, Assistant professor, Department of Microbiology, Faculty of Medical Laboratory Sciences, University of Elimam Elmahdi, Kosti City, Sudan, Tel: +0123564448; E-mail: aumahd2010@gmail.com

Received date: February 3, 2018; Accepted date February 8, 2018; Published date: February 15, 2018

Copyright: () 2018 Osman MB, et al. This is an open-access article distributed under the terms of the Creative Commons Attribution License, which permits unrestricted use, distribution, and reproduction in any medium, provided the original author and source are credited.

\begin{abstract}
Background: Mobile devices and hand of Healthcare Workers may contaminate with bacteria and become a source of infection.

Objective: This study was conducted to identify the types of bacteria in mobile phones, ears, and hands of healthcare workers (HCWs) in Kosti teaching hospital and to determine the frequency of MRSA among Staphylococcus auerus isolates from these specimens.

Materials and Methods: This was a cross-sectional, hospital and laboratory based study, was carried out in Kosti Teaching Hospital. A total of 120 swab samples were collected from mobile phone, hand and ear of healthcare workers. All the swabs were cultured directly on blood agar, MacConkey agar and chocolate agar. Identification of isolates was did base on colonial appearance, Gram stain, and conventional biochemical tests. All Staphylococcus auerus isolates were subjected to antibiotics susceptibility testing using disc diffusion technique. Data were analyzed by statistical package for social sciences (SPSS) software version 17 and presented in form of tables.
\end{abstract}

Results: The frequency of positive culture among mobile phone, ear, and hand swabs were 95\% (57/60), 100\% $(30 / 30)$ and $96.7 \%(29 / 30)$, respectively. The frequency of MRSA was $98.6 \%$.

Conclusions: Mobile phone, ear and hand of Healthcare Workers were the source of nosocomial infections. Good basic hygiene measures are extremely important, not only for hospital staff but also for patients and visitors, and it has a positive impact in infection control.

Keywords: Healthcare; MRSA; Phone; Healthcare Workers; Nosocomial infections

\section{Introduction}

Mobile phones have become an important part of our lives, though they offer plenty of advantages, they are profile breeding site for infectious pathogens in hospitals and communities. Mobile devices uses in hospitals are of particular interest, as they have been implicated in the spread of hospital acquired infections [1,2]. Microbial contamination is commonly found on the mouth piece, although indirect contamination from person to person has decreased with the decline in the use of public payphones, cell phones with buttons and keyboards and other personal mobile phones in general has been found to be even more conducive to bacterial contamination $[3,4]$. Nosocomial infections pose a serious threat to hospitals all over the world. HealthCare workers (HCW) play a crucial role in spread and transmission of bacteria to hospitalized patients. Strict hygiene standards to prevent hospital acquired infection are of paramount importance in a hospital setting [5-7]. Therefore, the presence of a pathogen on a surface at any concentration may be a risk for transmission, and this is reflected in proposed guidelines for microbiological hygiene standards. In recent years, some studies have been conducted on the potential role played by hands and the mobile phones belonging to health workers and inpatients in the transmission of important nosocomial pathogens [8,9]. Absence of hygiene may result of colonization of ears, hands, and other part of health workers body with microorganisms and they become a source of infection for others. Staphylococcus auerus is a one of most common cause of nosocomial infection. Methicillin resistant Staphylococcus auerus (MRSA) has increased spread as a result of drug abuse [10,11]. MRSA is resistant to many commonly uses antibiotics includes pencillin and cephalosporins group. Unfortunately MRSA isolates which susceptible only for glycopeptides antibiotics are becoming multidrugs resistant $[11,12]$. The increase of contamination of mobile phones and hands of health workers with these bacterial (MRSA) strains can associate with increase of numbers and spread of nosocomial infection as a result of decreased susceptibility of these isolates to antibiotics. This study was conducted to identify the types of bacteria in mobile phones, ears, and hands of healthcare workers (HCWs) in Kosti teaching hospital and to determine the frequency of MRSA among Staphylococcus auerus isolates from these specimens.

\section{Materials and Methods}

This was a cross-sectional, hospital and laboratory based study, carried out in Kosti city, White Nile state, Sudan. During the period of August to October 2017 a total of 120 swab samples were collected from mobile phones, hands and ears of healthcare workers in Kosti Teaching Hospital. Each swab was rotated over the surface of both 
Page 2 of 3

sides of the tested mobile phone keypad, screen phones or Hand or Ear of healthcare workers. 60 samples were collected from mobile phones, 30 samples from hands and 30 samples from ears of healthcare workers. All the swabs were cultured directly on blood agar, MacConkey agar and chocolate agar (Himedia). All cultured plates were incubated aerobically at $37^{\circ} \mathrm{C}$ for 24 hours. The primary isolates were subcultured on nutrient agar (Himedia). Identification of isolates was did base on colonial appearance, Gram stain, and conventional biochemical tests [7]. All identified isolates were subjected to antibiotics susceptibility testing by disc diffusion technique according to Clinical and Laboratory Standards Institute (CLSI) 2011 guidelines using Oxicillin (OX) $1 \mu \mathrm{g}$ disc to detect MRSA [8].

\section{Antibiotics susceptibility testing}

Each isolate was grown on nutrient agar and incubated at $37^{\circ} \mathrm{C}$ for 24 hours, then using sterile wire loop, 3-5 well isolated colonies were emulsified in 3-4 $\mathrm{ml}$ of sterile physiological saline, and bacterial suspension equivalent to 0.5 McFarland was prepared. Each suspension was inoculated on Muller Hinton agar (Himedia) using sterile cotton swab. Using sterile forceps the Oxicillin (OX) $1 \mu \mathrm{g}$ disc (Bioanalyse) was placed on the surface of agar. Then each plate was incubated aerobically at $37^{\circ} \mathrm{C}$ for 18 hours. The diameter of each inhibition zone around each disc was measured in millimeter and the result was interpreted as sensitive or intermediate or resistant according to the interpretative chart [8].

\section{Ethical consideration}

The study was approved by Department of Microbiology-University of El Imam El Mahdi and Management of Kosti Teaching Hospital. Verbal consent was taken from each participant and all samples were collected after he/she accepted and knew that they are participating in clinical study.

\section{Data analysis}

All data were analyzed by statistical package for social sciences (SPSS) software version 17 and presented in form of tables.

\section{Results}

The frequency of positive culture among mobile phone, ear, and hand swabs were 95\% (57/60), 100\% (30/30) and 96.7\% (29/30), respectively. The frequency of isolated bacteria was displayed in Tables 1 and 2. Base on susceptibility of Staphylococcus auerus isolates to Oxicillin $1 \mu \mathrm{g}$, the frequency of MRSA was $98.6 \%$ as seen in Table 3 .

\begin{tabular}{|l|l|l|l|l|}
\hline \multirow{2}{*}{ Isolates } & \multicolumn{2}{|l|}{ Frequency } & \multirow{2}{*}{ Total } \\
\cline { 2 - 5 } & $\begin{array}{l}\text { Mobile } \\
\text { phones }\end{array}$ & $\begin{array}{l}\text { Ear } \\
\text { swabs }\end{array}$ & $\begin{array}{l}\text { Hand } \\
\text { swabs }\end{array}$ & \\
\hline Staphylococcus auerus & 32 & 16 & 22 & \multirow{2}{*}{70} \\
\hline Gram negative rod & 14 & 9 & 2 & 25 \\
\hline $\begin{array}{l}\text { Bacillus spp (Gram positive } \\
\text { rod) }\end{array}$ & 11 & 5 & 5 & 21 \\
\hline Total & 57 & 30 & 29 & - \\
\hline
\end{tabular}

Table 1: Distribution of isolates among samples.

\begin{tabular}{|l|l|l|}
\hline Type & Frequency & Percentage \\
\hline Proteus vulgaris & 9 & $36 \%$ \\
\hline Proteus mirabilis & 4 & $16 \%$ \\
\hline Salmonella para A & 3 & $12 \%$ \\
\hline Citrobacter freundii & 2 & $8 \%$ \\
\hline Klebsiella pneumonae & 1 & $4 \%$ \\
\hline Provedinicia spp & 1 & $4 \%$ \\
\hline Morgnella morganii & 1 & $4 \%$ \\
\hline Eschireichia coli & 1 & $4 \%$ \\
\hline Salmonella typhi & 1 & $4 \%$ \\
\hline Enterobacter spp & 1 & $4 \%$ \\
\hline Pseudomonas aeruginosa & 1 & $4 \%$ \\
\hline Total & 25 & $100 \%$ \\
\hline
\end{tabular}

Table 2: Frequency of Gram negative isolates.

\begin{tabular}{|l|l|l|l|}
\hline \multirow{2}{*}{ Antibiotic } & \multicolumn{2}{|l|}{ Frequency } \\
\cline { 2 - 4 } & Sensitive & Intermediate & Resistant \\
\hline Oxicillin $1 \mu \mathrm{gg}$ & $1.4 \%(1 / 70)$ & $0 \%(0 / 70)$ & $98.6 \%(69 / 70)$ \\
\hline
\end{tabular}

Table 3: Susceptibility of Staphylococcus auerus isolates to Oxicillin.

\section{Discussion}

Mobile phone, hands and other parts of body can colonize with bacteria and serve as source of infections. As displayed in this study the frequency of positive culture among mobile phone, ear, and hand swabs were $95 \%(57 / 60), 100 \%(30 / 30)$, and $96.7 \%(29 / 30)$, respectively, these results revealed that mobile phone, ears and hands of health workers may associated with transmission of bacterial infection to others as also reported by many other studies, due to colonization with bacteria that constitute the normal flora of the skin. These results agree with Pal S et al. study that reported $100 \%$ contamination was found in mobile phones and hands of HCWs indicating mobile phones can be potential source of nosocomial pathogens [9]. Also agree with Monaha A study that reported $100 \%$ contamination was detected in mobile phone [13].

In this study the highest bacterial contaminate was Staphylococcus auerus (70), followed by Gram negative bacilli (25) and bacillus $s p$ (21). The results which we have been got were an important and should be taken seriously as we reported the frequency of MRSA among Staphylococcus auerus isolates were 98.6\%. These findings agree with Pathare et al. study which revealed that many resistant strains of different isolates were prevalent in the mobile phones that indicates a marked resistance to the most commonly used antibiotics as MRSA strains [14]. And disagree with Pal et al. study that reported the frequency of MRSA among hands and phones of health workers was $5.7 \%$ [9]. Also disagree with Monahan et al. study that reported the frequency of MRSA among health care workers was 10\% [13]. The frequency of MRSA in Pal et al. and Monahan et al. study are lower 
Citation: Osman MB, Omer SM, Almugadam BS and Ahmed HM (2018) Frequency of MRSA Isolates in Mobile Phones, Ears and Hands of

when compare with our study which may due to the difference in study area and the used methods.

\section{Conclusions}

Mobile phone, ears and hands of Healthcare Workers were the source of nosocomial infections. Good basic hygiene measures are extremely important, not only for hospital staff but also for patients and visitors, and it has a positive impact in infection control.

\section{Conflicts of Interest Statement}

All authors declare that they have no competing interests.

\section{Funding}

This study has not been funded by any organization or institution. All authors funded and supported this work.

\section{Acknowledgment}

First, our great thanks to participant patients. Also we would like to acknowledge staffs of Kosti Teaching Hospital and Department of Microbiology-University of El Imam El Mahdi.

\section{References}

1. Muzslay M, Lee E, Alder S, Wilson P, Powles T, et al. (2013) Key pad mobile phones are associated with a significant increased risk of microbial contamination compared to touch screen phones. J Infect Prevent 14: 65-68.

2. Khan S, Shaikh AA (2012) Mobile phones: reservoir of infectious diseases in university premises, NED University. J Research 9: 35-43.

3. Ilusanya OAF, Adesanya OO, Adesemowo A, Amushan NA (2012) Personal hygein and microbial contamination of mobile phones of food vendors in ago-iwoye town, ogun state, Nigeria. Pakistan J Nutrit 11: 276-278.
4. Edem EN, Onwuezobe IA, Ochang EA, Etok CA, James IS (2013) Antibiogram of bacterial isolates from the anterior nares sand hands of health care workers in Unive- rsity of Uyo Teaching Hospital (UUTH) Uyo, AkwaIbom State, Nigeria. J Bacteriol Parasitol 4: 1-5.

5. Razine R, Azzouzi A, Barkat A, Khoudri I, Hassouni F, et al. (2012) Prevalence of hospital-acquired infections in the university medical center of Rabat, Morocco. Int Arch Med 5: 1-8.

6. Endalafer N, Selassie SG, Kotiso B (2010) Nosocomial bacterial infections in a tertiary hospital in Ethiopia. J Infection Prevent 12: 38-43.

7. Colle G, Fraser AG, Marmion BP, Simmons A (1996) Makie and McCarthey practical microbiology, Churchill Livingeston, 14 Edn. New York, USA.

8. Cockerill FR, Wikler MA, Bush K, Dudley MN, Eliopoulos GM, et al. (2011) Performance standards for antimicrobial susceptibility testing: twenty-fist informational supplement. CLSI 31.

9. Pal S, Juyal D, Adekhandi S, Sharma M, Prakash R, et al. (2015) Mobile phones: Reservoirs for the transmission of nosocomial pathogens. Adv Biomed Res 4: 144.

10. Armin S, Fallah F, Navidinia M, Vosoghian S (2017) Prevalence of blaOXA- 1 and blaDHA-1 AmpC $\beta$-lactamase-producing and methicillinresistant Staphylococcus aureus in Iran. Arch Pediatr Infect Dis 5: e36778.

11. Navidinia M, Fallah F, Lajevardi B, Shirdoost M, Jamali J (2015) Epidemiology of Methicillin-Resistant Staphylococcus aureus isolated from health care providers in mofid children hospital. Arch Pedia Infect Dis 3: e16458.

12. Navidinia M (2015) Detection of inducible clindamycin resistance (MLSBi) among methicillin resistant Staphylococcus aureus (MRSA) isolated from health care providers. J Paramed Sci 6: 2008-4978.

13. Safaar MAA (2017) Prevalence of methicillin resistant Staphylococcus aureus (MRSA) in mobile phone of healthcare workers in Baghdad teaching hospital. JMSCR 5: 17796-17803.

14. Pathare NA, Asogan H, Tejani S, Mahruqi GAL, Fakhri SA, et al. (2016) Prevalence of methicillin resistant Staphylococcus aureus [MRSA] colonization or carriage among health-care workers. J Infect Pub Health 9: 571-576. 